\title{
Evaluation and statistical interpretation of low-temperature geothermal energy potential for selected locations in Poland
}

\author{
Maciej R. KŁONOWSKI ${ }^{1, *}$, Jacek KOCYŁA ${ }^{2}$, Grzegorz RYŻYŃSKI ${ }^{2}$ and Mateusz ŻERUŃ ${ }^{2}$ \\ 1 Polish Geological Institute - National Research Institute, al. Jaworowa 19, 53-122 Wrocław, Poland \\ 2 Polish Geological Institute - National Research Institute, ul. Jagiellońska 76, 03-301 Warszawa, Poland
}

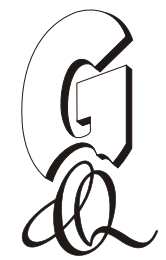

Kłonowski, M.R., Kocyła, J., Ryżyński, G., Żeruń, M., 2020. Evaluation and statistical interpretation of low-temperature geothermal energy potential for selected locations in Poland. Geological Quarterly, 64 (2): 506-514, doi: 10.7306/gq.1534

Associate Editor: Leszek Marks

Fulfilling the binding national, EU and other international regulations and requirements on climate and energy implies significant growth of renewables share in the total mix of energy production in Poland. Low-temperature geothermal energy extracted with the use of the ground source heat pumps (GSHP) is an efficient and reliable source for space heating, cooling and seasonal thermal energy storage and recovery, thus it contributes to reduction of low emissions and improvement of air quality. GSHP effectiveness is to a high degree determined by local geological and hydrogeological settings, therefore identification of natural properties of the subsurface is crucial for appropriate design and subsequent operation of the GSHP installations. The thermal conductivity $\lambda$ of rocks and soils, a key geothermal parameter, depends on such features as the mineral composition of rocks and soils, their texture and water content. Relevant geological data is retrieved from thematic databases, atlases and serial maps and can be gathered in a unitary database with a uniform structure to enable spatial analysis with the use of GIS techniques. Reclassification of lithological properties into geothermal parameters and subsequent calculations of $\lambda$ values $(\mathrm{W} / \mathrm{m} \cdot \mathrm{K})$ of rock and soil types can be made using a specific algorithm. The results of these calculations enables computation of four spatial layers of average geothermal conductivity coefficient $\lambda(\mathrm{W} / \mathrm{m} \cdot \mathrm{K})$, respectively for the depth intervals of $0-40,41-70,71-100$ and $101-130$ metres b.g.l.

Key words: low-temperature geothermal energy, geological databases, statistical analysis, GIS.

\section{INTRODUCTION}

The share of energy from renewable sources in final energy consumption in 2016 for EU28 amounted to $8.0 \%$, while for Poland it was $8.3 \%$ (Berent-Kowalska et al., 2019). In the same year the share of geothermal energy in total energy production from renewable energy sources (RES) reached 3.2 and $0.2 \%$ for UE28 and Poland, respectively. A new EU energy strategy called Clean Energy for all Europeans programme (European Commission, 2019) supports transition from fossil fuels towards cleaner decarbonized energy and, together with the revised Renewable Energy Directive, also called the RED II Directive (Directive 2018/2001/EU, 2018), sets new binding energy targets for 2030 covering an increase of renewables share of at least $32 \%$ and the enhancement of energy efficiency by $32.5 \%$. In addition, this requires growth of the share of RES in the heating and cooling sector by $1.3 \%$ per year at the national level between 2020 and 2030. Because of urgent problems concerning

\footnotetext{
* Corresponding author, e-mail: maciej.klonowski@pgi.gov.pl
} Received: August 9, 2019; accepted: February 18, 2019; first published online: May 19, 2020 air quality due to dust and $\mathrm{CO}_{2}$ emissions the necessity for decrease of low emissions from domestic sources and transportation, as well as for fulfillment of the requirements of the RED II Directive, is increasing attention on investments in low- and high-temperature geothermal energy installations in Poland (Kępińska, 2019).

Low-temperature geothermal energy, also called shallow or low-enthalpy geothermal energy, is thermal energy, of both endo- and exogenic origin, extracted from the uppermost part of the lithosphere, down to about two to four hundred metres depth. This conventionally adopted border varies greatly, depending on local and regional natural conditions and legal regulations, the scientific approach adopted, applied technologies and best practices. In Europe, the temperature of the shallow subsurface is changeable and depends on factors such as the ambient atmospheric air temperature. It stabilizes, however, at a depth of $\sim 15-20$ metres and below that depth it is to some extent governed by the local geothermal gradient. Therefore, the temperature of the shallow subsurface, the low-temperature geothermal system, can be steadily extracted throughout the year with use of ground-coupled heat pump installations (Self et al., 2013; Sarbu and Sebarchievici, 2014; Casasso et al., 2017) and successfully contribute to spatial heating and cooling, and thus to the decrease of low emissions (Nejat et al., 2015; García-Gil, 2020). These cover both: the open-loop systems 


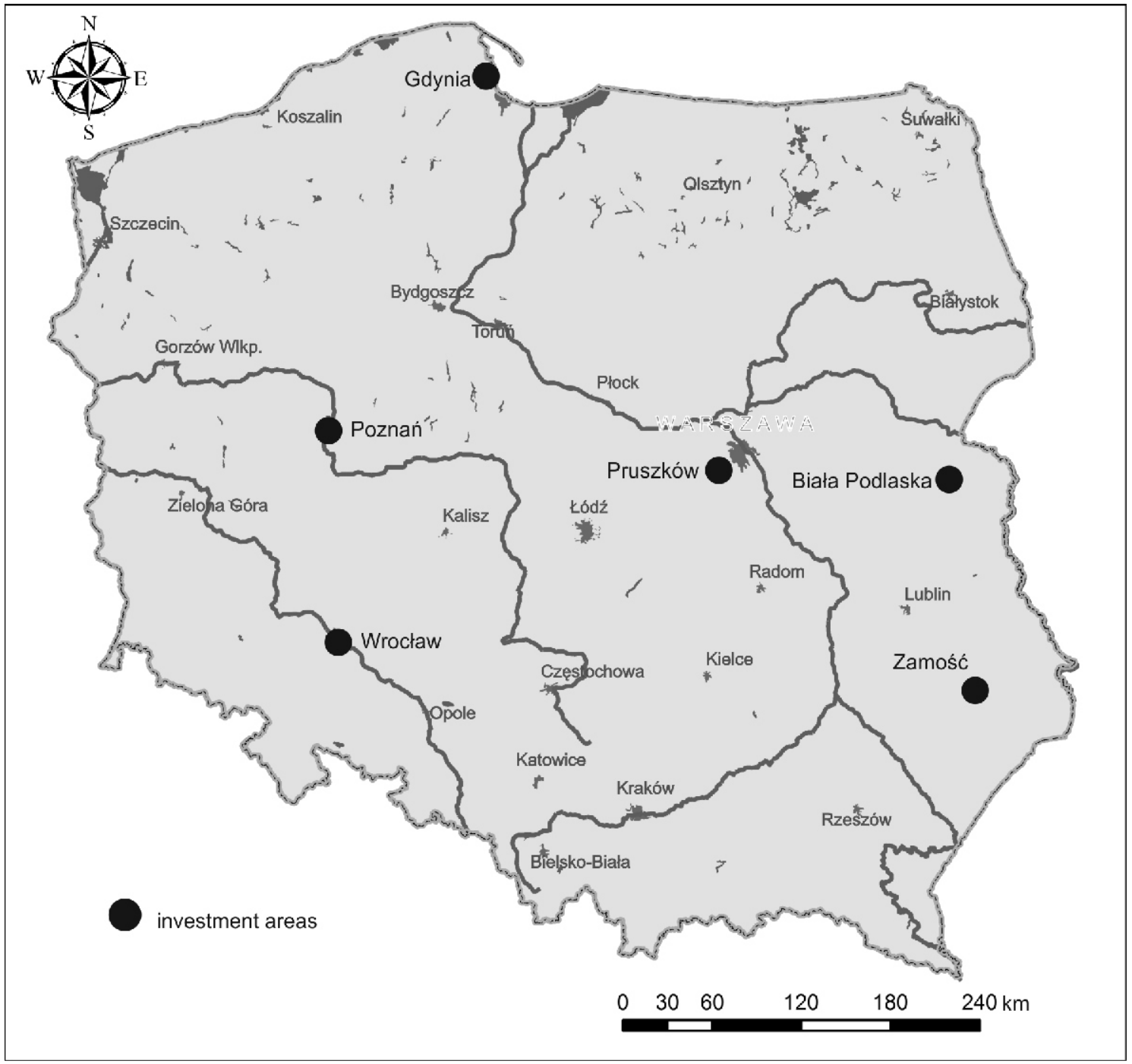

Fig. 1. Location of studied investment areas in Poland

with direct use of groundwater (groundwater heat pumps, GWHP); and the closed-loop systems, extracting temperature of the bulk subsurface comprising soils, rocks and groundwater (ground source heat pumps, GSHP). The research described in this paper refers exclusively to low-temperature geothermal energy governed, to a major extent, by the lithological properties of the soils and rocks (Luo et al., 2016) as well as the water content, both accounting for their thermal conductivity values, with little or no effect of the geothermal gradient, under natural conditions in Poland, extracted with use of GSHP installations with closed-loop systems mounted as borehole heat exchangers (BHE).

This paper presents the results of the bilateral Polish-Norwegian project Geothermal4PL - Support for the sustainable development and use of shallow geothermal energy in the areas covered by the Mieszkanie Plus programme in Poland, carried out between April and November 2017. The project focused on supporting sustainable development and utilization of low-temperature energy for residential housing by developing a methodology of geothermal mapping, including assessment of its potential. For the sake of the project, six investment areas of the Mieszkanie Plus programme (governmental programme for inexpensive and ecologically sound residential housing) in Poland were chosen for further detailed studies. These were located in the following cities and towns scattered across the country: Biała Podlaska, Gdynia,
Poznań, Pruszków near Warszawa, Wrocław and Zamość, the locations of which are indicated in Figure 1. The main selection criterion was the possibility to access cadastral data and the approval of local spatial management plans, as well as the occurrence of diverse geological and hydrogeological settings for better comparative analysis of the natural properties studied. Because of small geographic extent of the investment sites, a two kilometre-wide buffer zone in the form of a circle was created for each of them. All further research and analysis of geothermal parameters were performed within these buffer zones.

Except for the Mieszkanie Plus programme, private investments in renewable energy sources for heating and cooling are supported by the Czyste Powietrze (Eng. Clean Air) programme, currently run in Poland since 2018 by the National Fund for Environmental Protection and Water Management. This offers private investors in the residential housing sector a wide range of incentives. The major objective of the programme is to improve the energy effectiveness of the buildings and to reduce gas and dust emissions. In addition, recent dynamic developments of GSHP installations in Poland have been stimulated by the development of professional methodology for the deployment and operation of new installations, as well as by broad public acceptance and support for ecologically sound technologies for heating and cooling (Lachman et al., 2013; Kłonowski et al., 2018). 


\section{GEOLOGICAL AND HYDROGEOLOGICAL SETTINGS}

The investigated investment sites represent places showing diverse geological and hydrogeological conditions, studied up to an average depth slightly exceeding 100 metres below ground level (b.g.I.), adopted as the maximum depth for the sake of this research. The majority of the locations studied are situated on Quaternary deposits of glacial, fluvial, glaciofluvial, lacustrine and eolian origin, characterized by highly variable thickness and strongly heterogeneous lithostratigraphy. These are normally composed of interbedded, low- to highly-permeable deposits such as tills, loams, clays, sandy tills, sands and gravels. Most of the sand and gravel layers form continuous aquifers and/or water-saturated lenses embedded within the deposits showing lower-permeability. The largest thicknesses of highly permeable deposits, up to 20 and locally 50 metres, can be found in Biała Podlaska (Pietruszka and Zezula, 2004), Gdynia (Orłowski and Lidzbarski, 1998) and Pruszków (Mianowski, 1997).

For each of the sites selected, the groundwater table of the shallow aquifers is situated usually at depths of $5-15 \mathrm{~m}$ b.g.l. The geological conditions for Zamość area are different. Here, the shallow deposits are represented by the tills, partly deposited on Quaternary sands of a total thickness of $30 \mathrm{~m}$, and partly on Upper Cretaceous marls and limestones (CzerwińskaTomczyk and Sadurski, 1998). In Poznań (Dąbrowski et al., 2000) and Wrocław, the geology is mainly represented by glacial tills, loams and silts, occasionally interbedded with thin sand and gravel layers. The aquifers are normally associated with Neogene sands and gravels embedded within thick clay deposits at depths of 20-40 and 80-100 m (Żuk, 2000).

\section{DATA SOURCES AND PROCESSING}

For the proper assessment of low-temperature geothermal systems and their potential for heating and cooling it is necessary to use all accessible sources of geological and hydro- geological information and data. This provides for optimal design and subsequent operation of low-temperature geothermal installations. Consideration of all data sources, including databases and archives, is essential for proper interpretation of local geology and hydrogeology, and leads towards preparation of cross-sections, virtual boreholes and appropriate logs of the GSHP installations being designed. For that reason, especially useful is the Central Hydrogeological Database $(\mathrm{CBDH})$, where data from logs of hydrogeological boreholes, water intakes and springs, including lithostratigraphic and hydrogeological information, are stored (Cabalska et al., 2005). Table 1 shows the main sources of geological and hydrogeological data and information to be used for assessment of shallow geothermal systems. The following databases and serial thematic maps have been developed and maintained by the Polish Geological Institute - National Research Institute:

- SMGP: Detailed Geological Map of Poland;

- MHP: Hydrogeological Map of Poland;

- CBDH: Central Hydrogeological Database;

- CBDG: Central Geological Database;

- BDGI: Geological-Engineering Database.

While processing geological data for the assessment of shallow geothermal systems and low-temperature geothermal energy potential, it is crucial to consider proper collection and verification of geological and hydrogeological borehole data. The next step is to prepare appropriate attribute tables and algorithms used for calculation of thermal parameters for the selected depth intervals. An algorithm applied to processing of geological data for evaluation of low-temperature geothermal energy is shown in Figure 2. In such an approach, the spatial geological, environmental, topographic datasets ought to be appropriately designed and embedded into the database structures of a GIS environment, using open source and/or commercial software. The starting point for all calculations is an integrated geological borehole dataset containing complete information about the position, lithological log, depth of groundwater table and average geothermal parameters, i.e.: conductivity $\lambda$ $(\mathrm{W} / \mathrm{m} \cdot \mathrm{K})$ and geothermal power unit $\mathrm{q}_{\mathrm{v}}(\mathrm{W} / \mathrm{m})$, calculated for the individual lithological layers. Only verified and integrated data

Sources of geological information and data for evaluation of low-temperature geothermal energy potential

\begin{tabular}{|c|c|c|c|}
\hline $\begin{array}{l}\text { Map or data- } \\
\text { base } \\
\text { acronym }\end{array}$ & Scale & Content & Application for GSHP design \\
\hline SMGP & $1: 50 \mathrm{k}$ & $\begin{array}{l}\text { Detailed Geological Map of Poland: shows geo- } \\
\text { logical conditions, including: rocks and tectonic } \\
\text { features cropping out on the ground surface. }\end{array}$ & $\begin{array}{l}\text { The SMGP is one of the principal maps supporting } \\
\text { geological investigations of the planned geothermal } \\
\text { installations. }\end{array}$ \\
\hline MHP & $1: 50 \mathrm{k}$ & $\begin{array}{c}\text { Hydrogeological Map of Poland: shows } \\
\text { hydrogeological conditions, including: groundwa- } \\
\text { ter occurrence, hydrodynamics, quantity and qual- } \\
\text { ity of major aquifers. }\end{array}$ & $\begin{array}{c}\text { The MHP is one of the principal supporting maps } \\
\text { helping hydrogeological investigations of the } \\
\text { planned geothermal installations. }\end{array}$ \\
\hline $\mathrm{CBDH}$ & variable & $\begin{array}{c}\text { Central Hydrogeological Database: contains } \\
\text { hydrogeological borehole data, groundwater in- } \\
\text { takes, etc. }\end{array}$ & $\begin{array}{l}\text { Borehole logs from the CBDH are the basic source } \\
\text { of hydrogeological data for development of the ex- } \\
\text { pected geological log at the sites studied for the } \\
\text { planned geothermal installations. }\end{array}$ \\
\hline CBDG & variable & $\begin{array}{l}\text { Central Geological Database: contains data for } \\
\text { the Geological Map of Poland at 1:500 000 scale } \\
\text { as well as geological borehole data, results of } \\
\text { geophysical research, etc. }\end{array}$ & $\begin{array}{l}\text { Borehole logs from the CBDG are the basic source } \\
\text { of geological data for development of the expected } \\
\text { geological log at the sites studied for the planned } \\
\text { geothermal installations. }\end{array}$ \\
\hline BDGI & $1: 10 \mathrm{k}$ & $\begin{array}{c}\text { Geological-Engineering Database: contains data } \\
\text { for engineering-geological atlases of selected ur- } \\
\text { ban agglomerations, including boreholes and the- } \\
\text { matic maps. }\end{array}$ & $\begin{array}{l}\text { Borehole logs from the BDGI are the basic source of } \\
\text { geo-engineering data for development of the ex- } \\
\text { pected geological log at the sites studied for the } \\
\text { planned geothermal installations. }\end{array}$ \\
\hline
\end{tabular}


Results of the average thermal conductivity $\lambda_{\mathrm{av}}(\mathrm{W} / \mathrm{m} \cdot \mathrm{K})$ calculations for the depth interval of $0-40 \mathrm{~m}$

\begin{tabular}{|c|c|c|c|c|c|c|c|}
\hline Numer_id & Rzedna & Glub & Database & $\lambda_{\mathrm{av}}$ & sr_qvk_t18 & sr_qvr_t18 & sr_qvo_t18 \\
\hline 8639 & 141.0 & 58.7 & CBDG & 1.8 & 43.4 & 50.0 & 56.7 \\
\hline 8641 & 149.8 & 95.0 & CBDG & 1.6 & 48.5 & 55.7 & 62.8 \\
\hline 58052 & 142.0 & 75.0 & CBDG & 1.8 & 50.8 & 57.5 & 64.3 \\
\hline 58084 & 146.5 & 70.0 & CBDG & 1.6 & 35.0 & 42.5 & 50.0 \\
\hline 58093 & 138.3 & 52.6 & CBDG & 1.7 & 50.3 & 57.1 & 64.0 \\
\hline 58117 & 142.1 & 64.0 & CBDG & 1.8 & 49.3 & 56.1 & 63.0 \\
\hline 3173573 & 145.5 & 42.0 & CBDG & 1.7 & 44.0 & 50.3 & 56.5 \\
\hline 3173574 & 147.4 & 68.3 & CBDG & 1.7 & 48.2 & 55.0 & 61.9 \\
\hline 5680004 & 138.3 & 52.6 & $\mathrm{CDBH}$ & 1.9 & 60.1 & 67.5 & 75.0 \\
\hline 5680007 & 146.0 & 70.0 & $\mathrm{CDBH}$ & 1.9 & 47.0 & 54.3 & 61.6 \\
\hline 5680009 & 140.6 & 58.0 & $\mathrm{CDBH}$ & 1.5 & 34.3 & 39.5 & 44.8 \\
\hline 5680025 & 146.0 & 75.0 & $\mathrm{CDBH}$ & 1.8 & 51.9 & 58.7 & 65.6 \\
\hline 5680028 & 142.1 & 64.0 & $\mathrm{CDBH}$ & 1.8 & 49.4 & 56.7 & 64.0 \\
\hline 5680034 & 142.1 & 64.0 & $\mathrm{CDBH}$ & 1.9 & 61.7 & 69.0 & 76.3 \\
\hline 5680046 & 149.8 & 95.0 & $\mathrm{CDBH}$ & 1.4 & 37.3 & 43.8 & 50.3 \\
\hline 5680057 & 142.3 & 58.7 & $\mathrm{CDBH}$ & 1.8 & 52.4 & 59.5 & 66.6 \\
\hline 5680059 & 145.5 & 42.0 & $\mathrm{CDBH}$ & 1.8 & 47.8 & 54.6 & 61.5 \\
\hline 5680061 & 147.4 & 68.3 & $\mathrm{CDBH}$ & 1.8 & 50.7 & 57.7 & 64.6 \\
\hline 5680089 & 151.0 & 83.0 & $\mathrm{CDBH}$ & 1.7 & 47.6 & 54.5 & 61.3 \\
\hline 5680091 & 152.0 & 83.0 & $\mathrm{CDBH}$ & 1.7 & 50.2 & 57.0 & 63.8 \\
\hline 5680095 & 151.7 & 52.0 & $\mathrm{CDBH}$ & 1.6 & 47.3 & 54.2 & 61.1 \\
\hline 5680097 & 151.0 & 80.2 & $\mathrm{CDBH}$ & 1.8 & 52.6 & 59.5 & 66.3 \\
\hline 5680101 & 145.4 & 70.0 & $\mathrm{CDBH}$ & 1.8 & 53.2 & 60.2 & 67.3 \\
\hline 5680104 & 152.0 & 470.0 & $\mathrm{CDBH}$ & 1.7 & 49.4 & 56.3 & 63.1 \\
\hline 5680131 & 151.3 & 83.0 & $\mathrm{CDBH}$ & 1.7 & 46.3 & 53.1 & 60.0 \\
\hline
\end{tabular}

can be calculated further, using appropriate algorithms, to be a source for computation of the final results as tables, map compositions, geological cross-sections and logs.

\section{RESULTS AND INTERPRETATION}

Calculations performed under the terms of this research allowed for computing of basic thermal properties of soils and rocks including thermal conductivity for the 6 locations studied. Assessment of geothermal conditions was performed with use of archive borehole data only, as shown in Table 1. Table 2 shows average values of thermal conductivity $\lambda(\mathrm{W} / \mathrm{m} \cdot \mathrm{K})$ as the result of analysis for the selected depth intervals of $0-40$ 41-70, 71-100 and 101-130 m. The methodology of assessment of geothermal potential of the shallow geothermal systems studied at the selected sites was adopted by the authors from the results of the international GeoPLASMA-CE project published in the report Joint Report on Chosen Approaches and Methods for Calibration on the project website (GeoPLASMA-CE project, 2017).

The exact location and depth of each borehole can be deduced from its ID number shown in Table 2, while the item names used in Table 2 are described in Table 3 . This dataset is a basis for generation of the point data layers and preparation of the final maps, including that shown in Figure 3. In addition, for

Table 3

Explanation of abbreviations used in the geological database and Tables 2, 4-7

\begin{tabular}{|l|c|}
\hline \multicolumn{1}{|c|}{ Item abbreviation } & Description and unit \\
\hline numer_id & ID number of the borehole \\
\hline rzedna & altitude of the borehole, metres above mean sea level [m a.m.s.I.] \\
\hline depth BGL & depth of the borehole, metres below ground level [m b.g.I.] \\
\hline glub & total depth of the borehole, metres [m] \\
\hline baza & the source database \\
\hline sr_w_la & average value of thermal conductivity $\lambda_{\text {av. }}[\mathrm{W} / \mathrm{m} \cdot \mathrm{K}]$ \\
\hline sr_qvk_18 & average value of unit heat output (conservative assumptions) $\mathrm{q}_{\mathrm{v}}[\mathrm{W} / \mathrm{m}]$ \\
\hline sr_qvr_18 & average value of unit heat output (realistic assumptions) $\mathrm{q}_{\mathrm{v}}[\mathrm{W} / \mathrm{m}]$ \\
\hline sr_qvo_18 & average value of unit heat output (optimistic assumptions) $\mathrm{q}_{\mathrm{v}}[\mathrm{W} / \mathrm{m}]$ \\
\hline
\end{tabular}




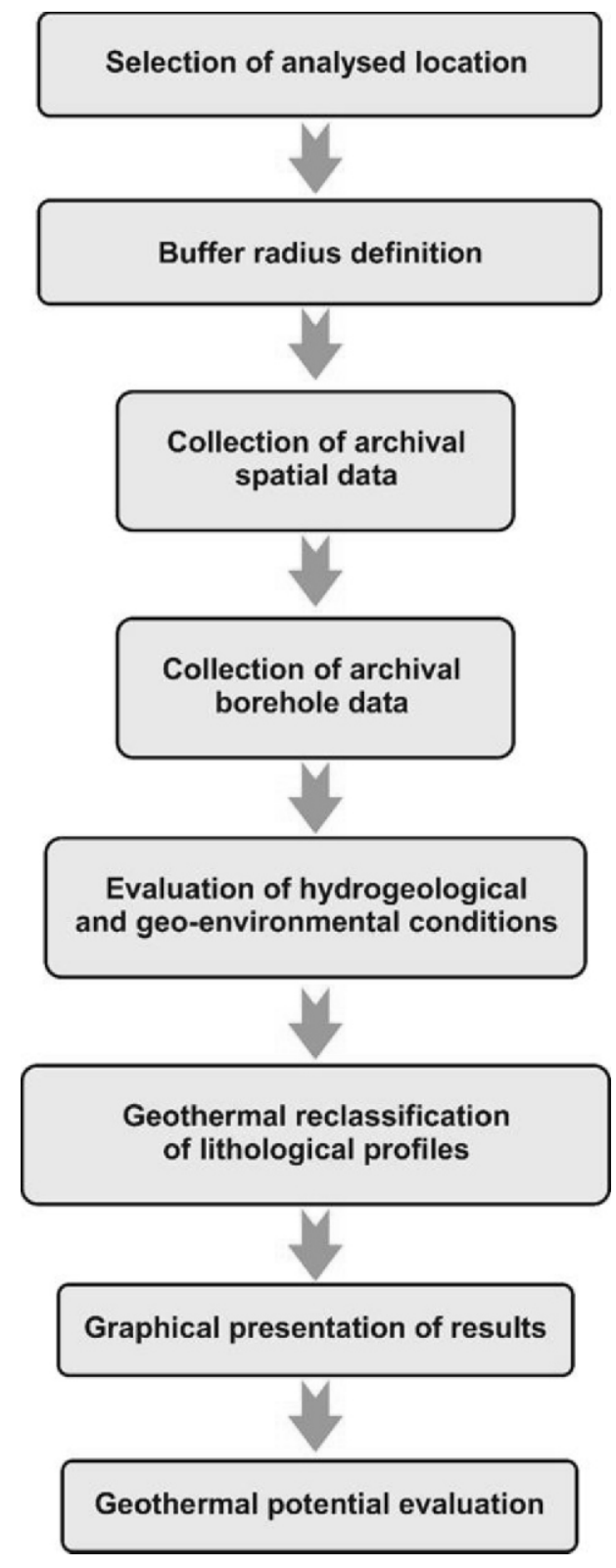

Fig. 2. Algorithm of geological data processing for evaluation of low-temperature geothermal energy each of the locations studied a synthetic geological cross-section was prepared. The example described in this paper is from the Biała Podlaska location.

The borehole data and values of geothermal parameters for the depth intervals of $0-40,41-70,71-100$ and $101-130 \mathrm{~m}$, for the Biała Podlaska location, are shown in Tables 4 and 5. As the basis for geothermal calculations of lithological divisions the PORT PC guidelines for the design manufacture and acceptance of heat pump installations (Part 1. Ground sources for heat pumps) was used (Lachman et al., 2013). The following elements for geothermal potential assessment have been taken into consideration:

- number and location of available archive boreholes: 31 boreholes per square kilometre;

- number of boreholes with description of lithological profiles for selected depths;

- values of average thermal conductivity and specific heat extraction rate for archive boreholes at selected depths;

- values of average thermal conductivity and specific heat extraction rate for synthetic profiles.

The results of the statistical evaluation (Tables 6 and 7) suggest that the most convenient geothermal conditions and underground properties can be found for the Zamość location. This is caused by presence of highly water-saturated complex of Quaternary sand and gravel layers underlain by a thick succession of Upper Cretaceous marls and limestones, heavily fractured and weathered.

The average value of thermal conductivity is shown in the archive boreholes on selected depths for the whole area, however, the average value of thermal conductivity $\lambda(\mathrm{W} / \mathrm{m} \cdot \mathrm{K})$ is assigned to virtual logs created uniquely for this research. The exact placement of the virtual profiles results from an optimization process performed with the use of GIS technology and software.

In Table 6 information about the number of boreholes in total at the given depth intervals, i.e.: 0-40, 41-70, 71-100 and $101-130 \mathrm{~m}$, is listed. Statistical analysis was performed for the dataset of archive borehole. The confidence interval of $95 \%$ is given in Table 6 ( \pm 2 standard deviations from the mean, assuming a normal distribution curve). Data provided in Tables 5 and 6 , showing the results of statistical evaluation, can be compared between the individual locations studied and ranked according to the criteria developed by the authors and adopted for this study. The criteria and ranking results are given in Table 8.

Results of statistical analysis of geothermal conditions for calculations of thermal conductivity $\lambda$

\begin{tabular}{|c|c|c|c|c|c|c|c|c|c|c|c|c|c|c|}
\hline \multirow{3}{*}{ 들 } & \multicolumn{6}{|c|}{$\begin{array}{c}\text { Borehole data } \\
\text { Analysed area: } 13.6 \mathrm{~km}^{2}\end{array}$} & \multicolumn{4}{|c|}{$\begin{array}{c}\text { Average thermal conductivity } \\
\lambda_{\mathrm{av} .}(\mathrm{W} / \mathrm{m} \cdot \mathrm{K}) \\
- \text { archive boreholes } \\
\frac{\left(\lambda_{\mathrm{av} .}-2 \sigma\right) \div\left(\lambda_{\mathrm{av} .}+2 \sigma\right)}{\lambda_{\mathrm{av}}}\end{array}$} & \multicolumn{4}{|c|}{$\begin{array}{c}\text { Thermal conductivity derived from synthetic } \\
\text { profile } \\
\lambda \cdot(\mathrm{W} / \mathrm{m} \cdot \mathrm{K})\end{array}$} \\
\hline & \multirow{2}{*}{ 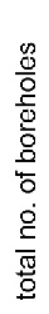 } & \multirow{2}{*}{ 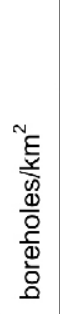 } & \multicolumn{4}{|c|}{ depth BGL } & \multicolumn{4}{|c|}{ depth BGL } & \multicolumn{4}{|c|}{ depth BGL } \\
\hline & & & 움 & 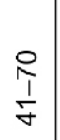 & $\frac{8}{\frac{1}{1}}$ & $\frac{\stackrel{m}{\frac{m}{1}}}{\frac{0}{\circ}}$ & 웅 & $\frac{i}{\frac{1}{2}}$ & $\frac{8}{\frac{1}{1}}$ & $\frac{\stackrel{9}{\frac{m}{1}}}{\frac{1}{\circ}}$ & 웅 & $\frac{i}{\frac{1}{1}}$ & $\frac{\frac{8}{1}}{\frac{1}{i}}$ & $\frac{\stackrel{m}{\frac{1}{1}}}{\frac{1}{6}}$ \\
\hline Biała Podlaska & 31 & 2.3 & 25 & 12 & 1 & 1 & $\frac{1.48 \div 1.98}{1.73}$ & $\frac{1.48 \div 2.02}{1.75}$ & $\frac{1.84}{1.84}$ & $\frac{1.83}{1.83}$ & 1.62 & 1.66 & 1.72 & 1.74 \\
\hline
\end{tabular}


Results of statistical analysis of geothermal conditions for calculations of specific heat extraction rate $q_{v}$

\begin{tabular}{|c|c|c|c|c|c|c|c|c|c|c|c|c|c|c|}
\hline \multirow{3}{*}{ 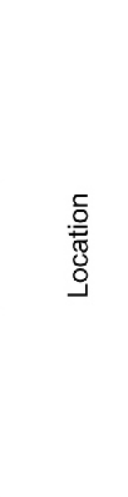 } & \multicolumn{6}{|c|}{$\begin{array}{c}\text { Borehole data } \\
\text { Analysed area: } 13.6 \mathrm{~km}^{2}\end{array}$} & \multirow{2}{*}{\multicolumn{4}{|c|}{$\begin{array}{l}\text { Average specific heat extraction rate } \\
q_{v \text { av }}(\text { W/m) } \\
\text { calculated for archive boreholes } \\
\frac{\left(q_{v} \text { sr }-2 \sigma\right) \div\left(q_{v} \text { sr }-2 \sigma\right)}{q_{v} \text { av. }} \\
\text { depth BGL }\end{array}$}} & \multirow{2}{*}{\multicolumn{4}{|c|}{$\begin{array}{l}\text { Specific heat extraction rate } \\
\text { calculated for synthetic profile } \\
\mathrm{q}_{\mathrm{v} \text { av. }}(\mathrm{W} / \mathrm{m})\end{array}$}} \\
\hline & \multirow{2}{*}{ 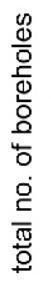 } & \multirow{2}{*}{ 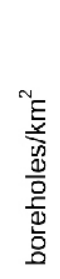 } & \multicolumn{4}{|c|}{ depth BGL } & & & & & & & & \\
\hline & & & 웅 & $\frac{0}{\frac{1}{4}}$ & $\frac{8}{\frac{1}{1}}$ & $\frac{\text { 음 }}{\frac{1}{5}}$ & श & $\frac{P}{\frac{1}{4}}$ & $\frac{\frac{8}{1}}{\frac{1}{n}}$ & $\frac{\stackrel{\oplus}{\frac{1}{1}}}{\frac{1}{\square}}$ & 导 & $\frac{0}{\frac{1}{1}}$ & $\frac{\frac{8}{1}}{\frac{1}{1}}$ & $\frac{\stackrel{0}{\frac{m}{1}}}{\frac{1}{0}}$ \\
\hline $\begin{array}{l}\text { Biała } \\
\text { Podlaska }\end{array}$ & 31 & 2.3 & 25 & 12 & 1 & 1 & $\frac{42.1 \div 68.4}{55.2}$ & $\frac{43.4 \div 69.8}{56.5}$ & $\begin{array}{l}\frac{57.4}{57.4} \\
\end{array}$ & $\begin{array}{l}\frac{55.1}{55.1} \\
\end{array}$ & 55.8 & 55.9 & 54.0 & 52.3 \\
\hline
\end{tabular}

Table 6

Assessment of geothermal conditions for the locations studied - analysis of the values of thermal conductivity $\lambda$

\begin{tabular}{|c|c|c|c|c|c|c|c|c|c|c|c|c|c|c|}
\hline \multirow{3}{*}{.ొ. } & \multicolumn{6}{|c|}{$\begin{array}{c}\text { Borehole data } \\
\text { Analysed area: } 12.5 \mathrm{~km}^{2}\end{array}$} & \multicolumn{4}{|c|}{$\begin{array}{l}\text { Average thermal conductivity } \\
\text { calculated for archive data } \\
\lambda_{\mathrm{avv}}(\mathrm{W} / \mathrm{m} \cdot \mathrm{K}) \\
\frac{\left(\lambda_{\mathrm{av}}-2 \sigma\right) \div\left(\lambda_{\mathrm{sr}}-2 \sigma\right)}{\mathrm{q}_{\mathrm{v} \text { av. }}}\end{array}$} & \multicolumn{4}{|c|}{$\begin{array}{l}\text { Thermal conductivity calculated } \\
\text { for synthetic profile } \\
\lambda_{1}(\mathrm{~W} / \mathrm{m} \cdot \mathrm{K})\end{array}$} \\
\hline & \multirow{2}{*}{$\begin{array}{l}\frac{0}{0} \\
\frac{0}{0} \\
\frac{0}{0} \\
\frac{0}{0} \\
\frac{8}{0} \\
\stackrel{0}{0} \\
\dot{0}\end{array}$} & \multirow{2}{*}{ 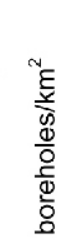 } & \multicolumn{4}{|c|}{ depth BGL } & \multicolumn{4}{|c|}{ depth BGL } & \multicolumn{4}{|c|}{ depth BGL } \\
\hline & & & 웅 & $\frac{R}{\frac{1}{d}}$ & $\frac{8}{\frac{0}{1}}$ & $\frac{\stackrel{\circ}{m}}{\frac{m}{1}}$ & I & $\frac{?}{\frac{1}{4}}$ & $\frac{8}{\frac{8}{1}}$ & $\frac{\substack{0 \\
\frac{1}{0}}}{2}$ & 웅 & $\frac{R}{\frac{1}{y}}$ & $\frac{8}{\frac{1}{1}}$ & $\frac{\stackrel{p}{\frac{m}{1}}}{\stackrel{0}{c}}$ \\
\hline $\begin{array}{l}\text { Biała } \\
\text { Podlaska }\end{array}$ & 31 & 2.48 & 25 & 12 & 1 & 1 & $\frac{1.48 \div 1.98}{1.73}$ & $\frac{1.48 \div 2.02}{1.75}$ & $\frac{1.84}{1.84}$ & $\frac{1.83}{1.83}$ & 1.62 & 1.66 & 1.72 & 1.74 \\
\hline Gdynia & 38 & 3.04 & 32 & 13 & 7 & 7 & $\frac{0.41 \div 1.64}{1.03}$ & $\frac{0.97 \div 1.74}{1.35}$ & $\frac{1.37 \div 1.62}{1.5}$ & $\frac{1.51 \div 1.69}{1.6}$ & 1.26 & 1.46 & 1.62 & 1.68 \\
\hline Poznań & 353 & 28.24 & 17 & 17 & 16 & 10 & $\frac{0.05 \div 1.95}{1}$ & $\frac{0.45 \div 2.05}{1.25}$ & $\frac{0.66 \div 2.06}{1.36}$ & $\frac{1.02 \div 2.10}{1.56}$ & 0.61 & 0.92 & 1.15 & 1.22 \\
\hline Pruszków & 312 & 24.96 & 67 & 12 & 10 & 10 & $\frac{1.40 \div 2.13}{1.77}$ & $\frac{0.85 \div 2.47}{1.66}$ & $\frac{0.75 \div 2.58}{1.66}$ & $\frac{0.75 \div 2.6}{1.67}$ & 1.84 & 1.9 & 1.94 & 1.95 \\
\hline Wrocław & 94 & 7.52 & 39 & 39 & 31 & 10 & $\frac{0.42 \div 2.19}{1.3}$ & $\frac{0.68 \div 2.33}{1.51}$ & $\frac{0.91 \div 2.31}{1.61}$ & $\frac{1.73 \div 1.93}{1.83}$ & 1.56 & 1.75 & 1.8 & 1.84 \\
\hline Zamość & 53 & 4.24 & 45 & 22 & 3 & 0 & $\frac{1.26 \div 2.40}{1.83}$ & $\frac{1.67 \div 2.32}{2}$ & $\frac{2.08 \div 2.29}{2.19}$ & no data & 1.59 & 1.93 & 2.04 & 2.1 \\
\hline
\end{tabular}


Table 7

Assessment of low-temperature geothermal energy potential for the depth up to $70 \mathrm{~m}$ b.g.l. based on the values of thermal conductivity $\lambda$

\begin{tabular}{|c|c|c|c|c|c|c|c|c|c|}
\hline \multirow[t]{2}{*}{ Location } & \multicolumn{2}{|c|}{$\begin{array}{c}\text { Thermal } \\
\text { conductivity } \\
\lambda_{1}(\mathrm{~W} / \mathrm{m} \cdot \mathrm{K}) \\
\text { for synthetic profile }\end{array}$} & \multicolumn{2}{|c|}{$\begin{array}{c}\text { Average thermal } \\
\text { conductivity } \\
\lambda_{\text {av }}(\mathrm{W} / \mathrm{m} \cdot \mathrm{K}) \\
\text { for archive data }\end{array}$} & \multicolumn{2}{|c|}{$\begin{array}{c}\lambda_{1}-\lambda_{\text {av }} \\
(W / \mathrm{m} \cdot \mathrm{K})\end{array}$} & \multicolumn{2}{|c|}{ Borehole $/ \mathrm{km}^{2}$} & \multirow[t]{2}{*}{$\begin{array}{l}\text { Total } \\
\text { ranking } \\
\text { points }\end{array}$} \\
\hline & & rank & & rank & & rank & & rank & \\
\hline Zamość & 1.93 & 3 & 2.00 & 3 & 0.07 & 3 & 1.7 & 2 & 11 \\
\hline Pruszków & 1.90 & 3 & 1.66 & 2 & 0.24 & 1 & 0.9 & 1 & 7 \\
\hline Wrocław & 1.75 & 2 & 1.51 & 2 & 0.24 & 1 & 2.9 & 3 & 8 \\
\hline Biała Podlaska & 1.66 & 2 & 1.75 & 2 & 0.09 & 2 & 0.9 & 1 & 7 \\
\hline Gdynia & 1.46 & 2 & 1.35 & 2 & 0.11 & 2 & 0.9 & 1 & 7 \\
\hline Poznań & 0.92 & 1 & 1.25 & 1 & 0.33 & 1 & 1.2 & 2 & 5 \\
\hline
\end{tabular}

Table 8

Criteria and ranking for assessment of shallow geothermal systems and potential of low-temperature geothermal energy

\begin{tabular}{|c|c|c|}
\hline Criteria & Conditions & Ranking points \\
\hline \multirow{3}{*}{$\begin{array}{l}\text { Criterion } 1 \\
\text { thermal conductivity } \lambda(W / m \cdot K) \text { derived from the synthetic profile for } \\
\text { reclassification depth interval of } 40-70 \mathrm{~m} \text { b.g.l. }\end{array}$} & $\lambda_{1}>1.3$ & 1 \\
\hline & $\lambda_{1}=1.3 \div 1.8$ & 2 \\
\hline & $\lambda_{1}>1.8$ & 3 \\
\hline \multirow{3}{*}{$\begin{array}{l}\text { Criterion } 2 \\
\text { average thermal conductivity } \lambda_{\mathrm{av}}(\mathrm{W} / \mathrm{m} \cdot \mathrm{K}) \text { from archival boreholes for } \\
\text { reclassification depth interval of } 40-70 \mathrm{~m} \text { b.g.l. }\end{array}$} & $\lambda_{\text {av. }}<1.3$ & 1 \\
\hline & $\lambda_{\text {av. }}=1.3 \div 1.8$ & 2 \\
\hline & $\lambda_{\mathrm{av} .}>1.8$ & 3 \\
\hline \multirow{3}{*}{$\begin{array}{l}\text { Criterion } 3 \\
\text { difference between thermal conductivity value from synthetic profile and } \\
\text { statistically estimated from archival boreholes } \lambda_{1}-\lambda_{\text {av. }}(\mathrm{W} / \mathrm{m} \cdot \mathrm{K})\end{array}$} & $\lambda_{1}-\lambda_{\mathrm{av} .}<0.08$ & 3 \\
\hline & $\lambda_{1}-\lambda_{\text {av. }}=0.08 \div 0.20$ & 2 \\
\hline & $\lambda_{1}-\lambda_{\text {av }}>0.20$ & 1 \\
\hline \multirow{3}{*}{$\begin{array}{l}\text { Criterion } 4 \\
\text { number of archive boreholes per square kilometre, reclassification depth } \\
\text { interval: } 40-70 \mathrm{~m} \text { b.g.l. }\end{array}$} & $<1$ & 1 \\
\hline & $1 \div 3$ & 2 \\
\hline & $>3$ & 3 \\
\hline
\end{tabular}




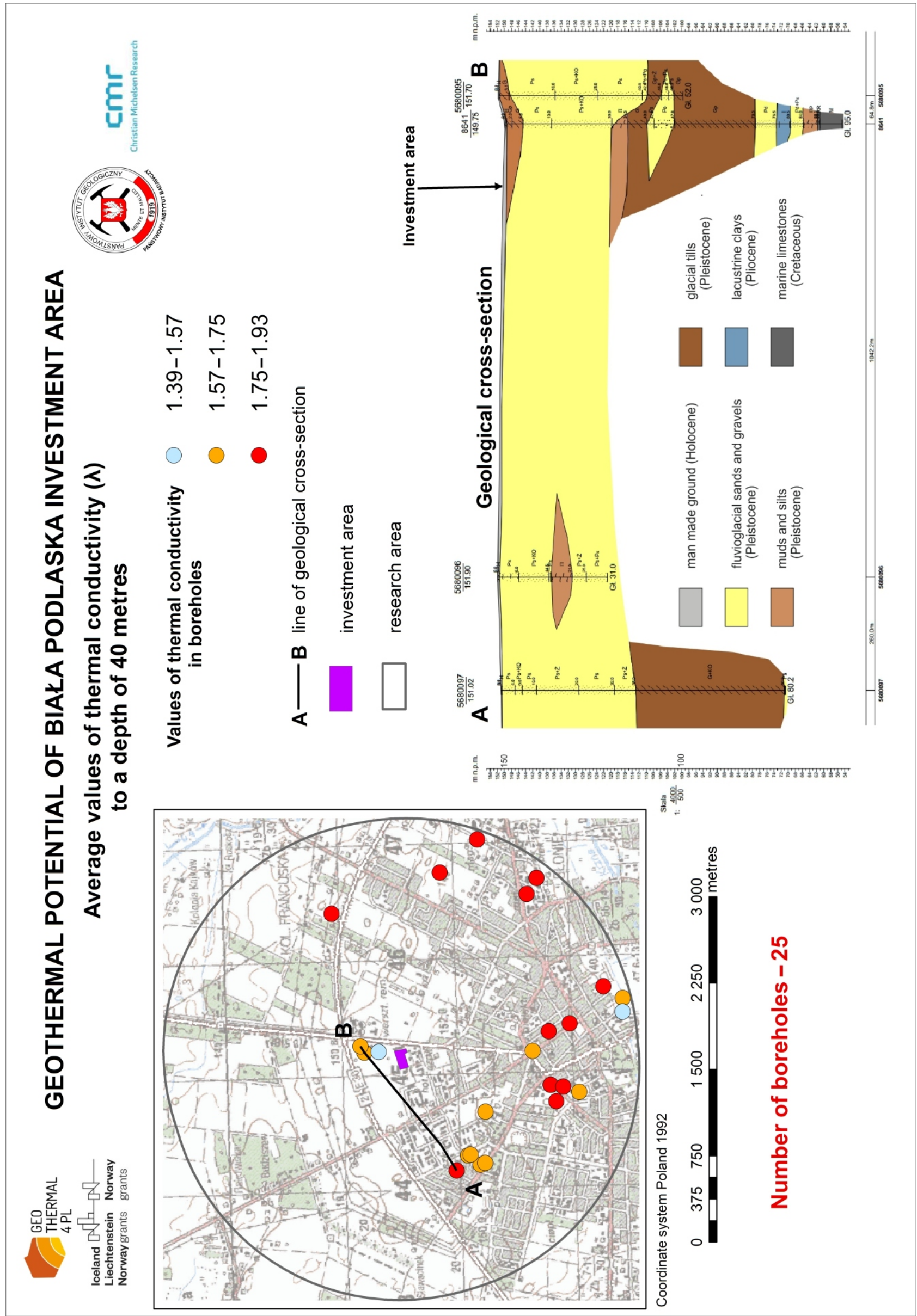

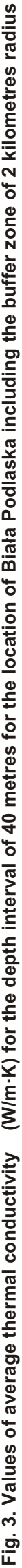




\section{SUMMARY AND CONCLUSIONS}

Within the framework of the Geothermal4PL project, geological and hydrogeological data were collected, verified and analysed (by reclassification processes) in order to assess the possibilities of use of shallow geothermal systems and the potential of low-temperature geothermal energy at six selected locations in Poland. The results indicate that ground source heat pumps are an effective and safe source of thermal energy for spatial heating and cooling as well as the production of warm tap water. The capacity of GSHP installations depends mainly on local geological and hydrogeological conditions. Hence, geological investigations, including reliable borehole data collection concerning lithostratigraphic logs and groundwater table position, are crucial for further calculations and evaluation. The next most important aspect while analysing the geothermal properties of the underground is the development of a lithological dictionary and further assignment of unique geothermal parameters to appropriate soil and rock types for subsequent reclassification and computation of results. This in turn allows for ranking of the selected locations with respect to the suitability of GSHP installations and potential capacity for low-temperature geothermal energy. In the au- thors' opinion the final results of the calculations, based on archive data sources, show rather underestimated parameter values. For the purpose of more precise thermal parameter evaluation it is necessary to perform some additional laboratory research, including examination of rock samples obtained directly from the boreholes located within the planned investment areas.

Acknowledgements. The authors acknowledge financing of the bilateral Polish - Norwegian project Geothermal4PL Support for the sustainable development and use of shallow geothermal energy in the areas covered by the Mieszkanie Plus programme in Poland, agreement number 102/2017/Wn50/ OA-XN-04/D, by the EEA Financial Mechanism 2009-2014 within the framework of the Bilateral Cooperation Fund (BCF), Programme PLO4 "Energy saving and promotion of renewable sources of energy". The authors are grateful for the contribution to the project of Dr. K. Midttømme of Christian Michelsen Research AS - the Norwegian partner of the project, and Prof. R. Kalskin Ramstad - the expert from the Norwegian University of Science and Technology. The authors thank the reviewer for constructive suggestions and remarks.

\section{REFERENCES}

Berent-Kowalska, G., Jurgaś, A., Kacprowska, J., Pawelczyk, M., Szymańska, M., 2019. Energy from renewable sources in 2018 (in Polish with English executive summary, table headings and figure captions). Statistics Poland, Warsaw.

Cabalska, J., Felter, A., Hordejuk, M., Mikołajczyk, A., 2005. The Polish Hydrogeological Survey Database Integrator - a new GIS tool for the hydrogeological database management useful in mapping process. Przegląd Geologiczny, 53: 917-920.

Casasso, A., Pestotnik, S., Rajver, D., Jez, J., Prestor, J., Sethi, R., 2017. Assessment and mapping of the closed-loop shallow geothermal potential in Cerno (Slovenia). Energy Procedia. In: European Geosciences Union General Assembly 2017. EGU Division Energy. Resources and Environment. ERE, Vienna.

Czerwińska-Tomczyk, J., Sadurski, A., 1998. Mapa Hydrogeologiczna Polski w skali 1:50 000, arkusz Zamość (862), główny poziom użytkowy (in Polish). Electronic version. Polish Geological Institute - National Research Institute, Warsaw.

Dąbrowski, S., Trzeciakowska, M., Straburzyńska, R., 2000 Mapa Hydrogeologiczna Polski w skali 1:50 000, arkusz Poznań (471), główny poziom użytkowy (in Polish). Electronic version. Polish Geological Institute - National Research Institute, Warsaw.

Directive 2018/2001/EU of the European Parliament and of the Council of 11 December 2018 on the promotion of the use of energy from renewable sources. Official Journal of the EU, 328: 82-209.

European Commission, 2019. Clean Energy for All Europeans Publications Office of the European Union, Luxembourg.

García-Gil, A., Goetzl, G., Kłonowski, M.R., Borovic, S., Boon D.P., Abesser, C., Janza, M., Herms, I., Petitclerc, E., Erlström, M., Holecek, J., Hunter, T., Vandeweijer, V.P., Cernak, R., Mejías Moreno, M., Epting, J., 2020. Governance of shallow geothermal energy resources. Energy Policy, 138: $1-11$.

GeoPLASMA-CE project, 2017. Joint Report on Chosen Approaches and Methods for Calibration on the project website. Viewed 10 February 2020, https://www.geoplasma-ce.eu/content.node/GeoPLASMA-CE/CE177-GeoPLASMA-CE-DT3.5.1Joint-report-on-chosen-approaches.pdf

Kępińska, B., 2019. Geothermal Energy Use - Country Update for Poland. 2016-2018. In: Proceedings of European Geothermal
Congress 2019, Den Haag, The Netherlands, 11-14.06.2019. The Hague.

Kłonowski, M.R., Kocyła, J., Ryżyński, G., Żeruń, M., 2018. Assessment of low-temperature geothermal energy potential based on analysis, interpretation and reclassification of geological data in urban areas (in Polish with English abstract). Technika Poszukiwań Geologicznych, Geotermia, Zrównoważony Rozwój, 57: 19-38.

Lachman, P., Mirowski, A., Oczoś, A., Karczmarzyk, A., Sawicki, C., Koczorowski, J., Smuczyńska, M., Franke, M., Zbrojkiewicz, S., 2013. Wytyczne projektowania wykonania i odbioru instalacji z pompami ciepła (in Polish). Polska Organizacja Rozwoju Technologii Pomp Ciepła PORT PC, Kraków.

Luo, J., Rohn, J., Xiang, W., Bertermann, D., Blum, P., 2016. A review of ground investigations for ground source heat pump (GSHP) systems. Energy and Buildings, 117: 160-175.

Mianowski, Z., 1997. Mapa Hydrogeologiczna Polski w skali 1:50 000, arkusz Pruszków (559), główny poziom użytkowy (in Polish). Electronic version. Polish Geological Institute - National Research Institute, Warsaw.

Nejat, P., Jomehzadeh, F., Taher, M.M., Gohari, M., Majid, M.Z., 2015. A global review of energy consumption. $\mathrm{CO}_{2}$ emissions and policy in the residential sector (with an overview of the top ten $\mathrm{CO}_{2}$ emitting countries). Renewable and Sustainable Energy Reviews, 43: 843-862.

Orłowski, R., Lidzbarski, M., 1998. Mapa Hydrogeologiczna Polski w skali 1:50 000, arkusz Gdynia (16), główny poziom użytkowy (in Polish). Electronic version. Polish Geological Institute - National Research Institute, Warsaw.

Pietruszka, W., Zezula, H., 2004. Mapa Hydrogeologiczna Polski w skali 1:50 000, arkusz Biała Podlaska (568), główny poziom użytkowy (in Polish). Electronic version. Polish Geological Institute - National Research Institute, Warsaw.

Sarbu, I., Sebarchievici, C., 2014. General review of groundsource heat pump systems for heating and cooling of buildings. Energy and Buildings, 70: 441-454.

Self, J.S., Reddy, V.B., Rosen, A.M., 2013. Geothermal heat pump systems: status review and comparison with other heating options. Applied Energy, 101: 341-348.

Żuk, U., 2000. Mapa Hydrogeologiczna Polski w skali 1:50 000, arkusz Wrocław (764), główny poziom użytkowy (in Polish). Electronic version. Polish Geological Institute - National Research Institute, Warsaw. 